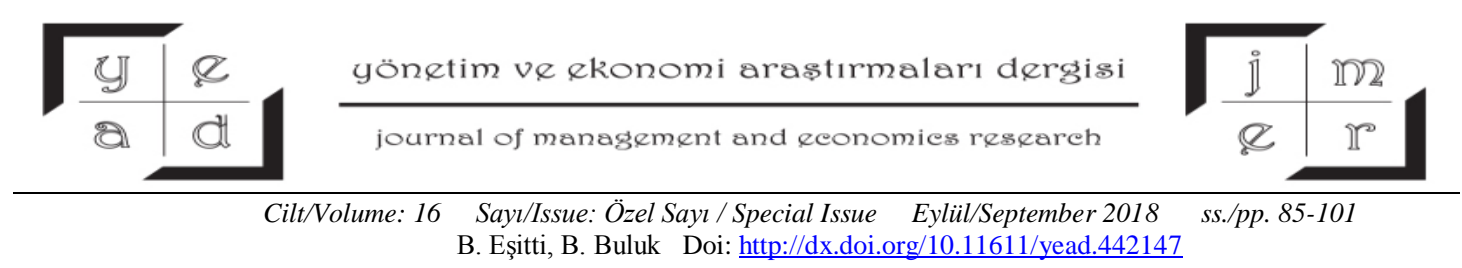

\title{
ATTRACTING TOURISTS TO CANAKKALE: THE POTENTIAL EFFECTS AND EXPECTATIONS OF THE YEAR OF TROY
}

\section{Ph.D. Bekir EŞiTTTi * id}

\section{Res. Asst. Buket BULUK * iD}

\begin{abstract}
The purpose of this study is to determine the potential effects and expectations of 'The Year of Troy' on attracting tourists and sustainable growth of Canakkale. In this context, promotional activities and events carried out within the scope of 'The Year of Troy' were evaluated. In addition, interviews were held with stakeholders and national-international tourists participating in the events. Interviews were conducted face-to-face by applying a semi-structured in-depth method. As a result, it can be said that the interest of Canakkale in the national and international area has increased remarkably in the first half of the year with the declaration of 2018 as 'The Year of Troy'. Local stakeholders are very hopeful about the positive impact of 'The Year of Troy' on Canakkale's tourism and are continuing to work in this direction. Participants of this study indicated that 'The Year of Troy' promoted regional tourism, increased number of tourists, revenues and coordination among tourism stakeholders in the first half of the year. It is also seen that the local stakeholders continue to be supported by the national government. It can be said that this support is an important determinant in the unification of local stakeholders and the revival of local tourism. Finally, it can be emphasized that the sustainability of this revival requires the protection of the national and local unity and long-term growth plans.
\end{abstract}

Keywords: Cultural Heritage, Sustainable Growth, Tourism Attractions, Troy, Canakkale.

JEL Classification: Z3, Z31, Z32.

\footnotetext{
* Canakkale Onsekiz Mart University, Tourism Faculty, Travel Management and Tourism Guidance Department, 17020, Canakkale, Turkey, e-mail: bekiresitti@comu.edu.tr

* Canakkale Onsekiz Mart University, Tourism Faculty, Accommodation Management Department, 17020, Canakkale, Turkey, e-mail: bulukbuket@comu.edu.tr
} 


\section{ÇANAKKALE'YE TURISSTLERİ ÇEKME: TROYA YILININ POTANSIYYEL ETKİLERİ VE BEKLENTILER}

\section{ÖZET}

Bu çalışmanın amacı, Çanakkale'ye turist çekme beklentileri ve Çanakkale'nin sürdürülebilir büyümesi üzerinde Truva Yılı'nın potansiyel etkilerini tespit etmektir. Bu bağlamda, Troya Yılı kapsamında gerçekleştirilen etkinlikler ve tanıtım faaliyetleri değerlendirilmiştir. Çalışma kapsamında ayrıca, paydaşlarla ve Troya yılı etkinliklerine katılan yerli ve yabancı turistlerle görüşmeler yapılmıştır. Görüşmeler yarı yapılandırılmış yüz yüze derinlemesine görüşme yöntemiyle gerçekleştirilmiştir. Çalışma sonucunda ilk olarak, 2018 'in Troya Yllı ilan edilmesi ile beraber 2018 'in ilk yarısında Çanakkale'ye olan ulusal ve uluslararası ilginin arttığı söylenebilir. Çalı̧̧madan elde edilen sonuçlar ayrıca, yerel paydaşların, 2018 Troya Yılı'nın Çanakkale'nin turizmine olumlu etkisi konusunda çok ümitli olduklarını ve bu yönde çalışmaya devam ettiklerini göstermektedir. Katılımcılar, yılın ilk yarısında "Troya Yılı" "nın bölge turizmini, turist sayısını, gelirlerini ve turizm paydaşlarının koordinasyonunu artırdı̆̆ını belirtmişlerdir. Bununla beraber, 2018 Troya yılı kapsamında yerel paydaşların ulusal hükümet tarafindan desteklenmeye devam ettiği de görülmektedir. Bu desteğin, yerel paydaşların birleşmesinde ve yerel turizmin canlanmasında önemli bir belirleyici olduğu söylenebilir. Son olarak, bu canlanmanın sürdürülebilirliği için, ulusal ve yerel birliğin korunması ve uzun vadeli büyüme planlarının yapılması gerektiği vurgulanabilir.

Anahtar Kelimeler: Kültürel Miras, Sürdürülebilir Büyüme, Turizm Çekicilikleri, Troya, Çanakkale.

JEL Sinıflandırması: Z3, Z31, Z32.

\section{INTRODUCTION}

Since the Second World War, tourism has grown rapidly and become one of the world's foremost economic phenomena (Deng et al. 2002). Depending on the development and growth potential of tourism 'sustainability' has become important as a result of the insight that the economic and environmental consequences of this rapidly growing industry can no longer be ignored (Gössling et al. 2002). The continuation of the tourism sectors unlimited growth in the global sense has led to the understanding of the sustainable use of resources. However the tourism understanding of Turkey remained as mass tourism in the sea-sand-sun triangle for a long time (Yıldırım \& Ölmez 2008). Turkey has begun to attach importance to the alternative tourism such as cultural heritage tourism after the increasing popularity of alternative tourism trends in the World.

With over five thousand years of history, Canakkale province as begun to attract the attention of local stakeholders and national government. Canakkale, just as Istanbul, connects the two main continents to one another. It consists of Gallipoli Peninsula in northwestern part of Turkey and Troas on the Biga Peninsula. It used to be named as Hellespont and Dardanelles in the ancient times (Anonymous 
2002). The province is an important natural and historical tourist attraction, both for Turkey and abroad visitors. The city has a low urbanization rate according to the other parts of the country and has a population which may be considered as static (Yıldırım \& Ölmez 2008). It is well known for its dark tourism sites (Gallipoli battlefields) and Trojan ruins. However, it has not achieved a sustainable increase in terms of number of tourists and income. The real history of Canakkale started with Troy. Troy is located some $30 \mathrm{kms}$ from Canakkale, was set up between 3500 - 3000 B.C. and thought to be one of the oldest residential areas of humanity. The ancient city of Troy, which has great significance for European history and literature, was included to the World Cultural Heritage List by UNESCO in 1998. The year 2018 is the twentieth anniversary of the inclusion of Troy into the UNESCO World Cultural Heritage. Due to the international recognition of the Troy, Turkey Culture and Tourism Ministry has declared the year 2018 as 'The Year of Troy', officially.

\section{Figure 1. Generalized Tourism Locations Map of Canakkale Province}

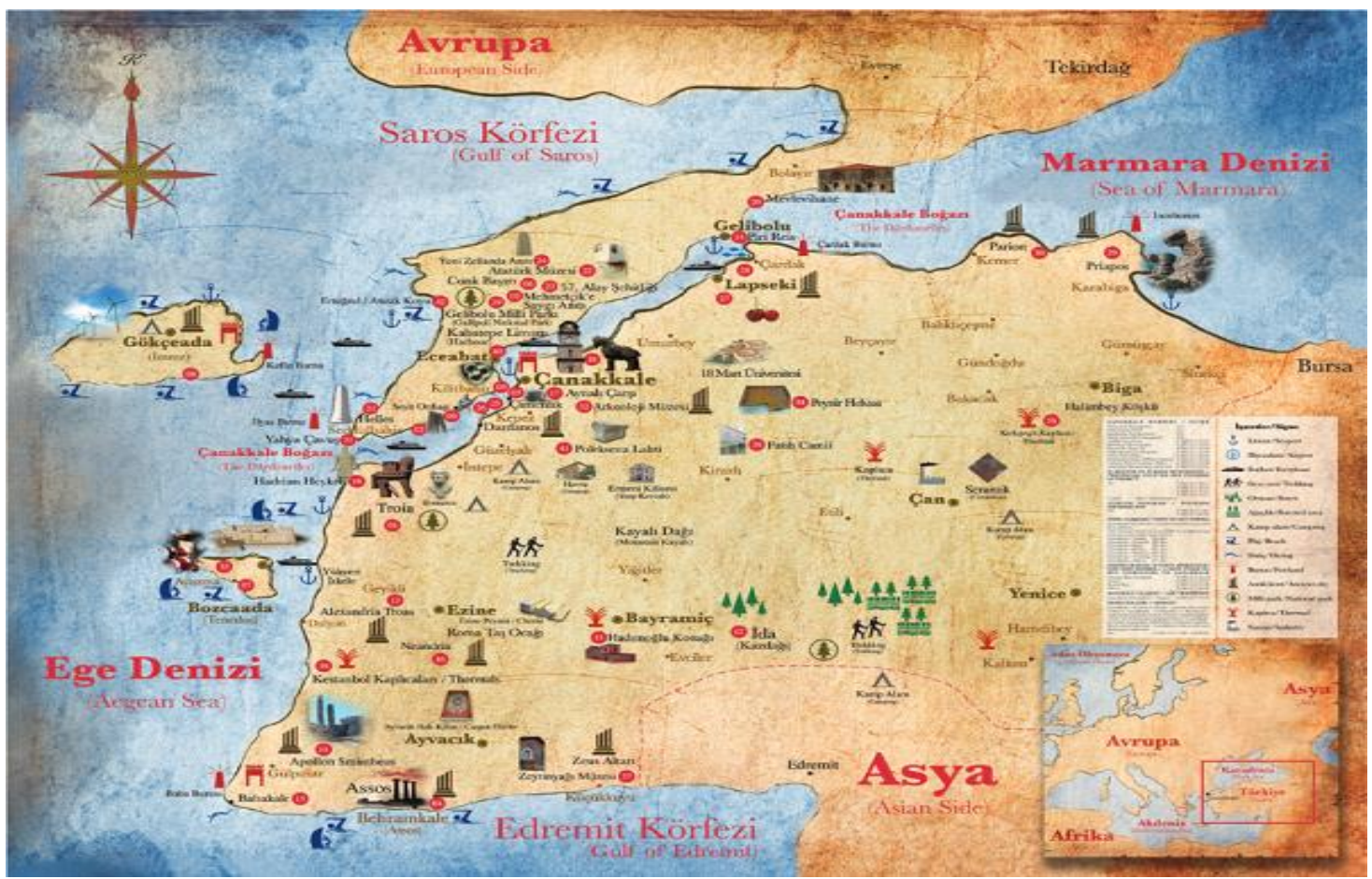

Source: Based on the Governorship of Canakkale's (2015) Regional Map.

Although the heritage tourism activities that mostly depend on a preserved historical heritages have positive economic social impacts, when it is not planned well, it may lead to exceed the carrying capacity and destruct the destination just as much as mass tourism. Tourism destinations are sensitive ecosystems and any tourism activity made without calculating the effects can also be potential drawbacks. In this context, the purpose of this study is to determine the potential effects and expectations of 'The Year of Troy' on attracting tourists and sustainable growth of Canakkale. The paper, first explains key potentials of the issues and illustrates how 'The year of Troy' activites organised and been applied in Canakkale province. The paper, second, gives expectations of the stakeholders on the economic/political and the environmental sustainability. 


\section{ATTRACTING TOURISTS TO A DESTINATION VIA CULTURAL HERITAGE}

Since the adoption in 1972 of the Convention Concerning the Protection of World Cultural Heritage, some 832 sites throughout the World have been formally designated as World Heritage Sites. There are 17 cultural heritage of Turkey in this list to this date (World Haritage List, 2018). These sites, by reason of their special historic, scientific, or esthetic qualities, have universal value. It is not surprising, therefore, that many sites are favorite tourist attractions (Drost, 1996). The European Union (EU) carries out an application, using cultural values to attract tourists, similar to Turkey. The application is named as 'European Capital of Culture'. EU designates a city for a period of one calendar year during which it organises a series of cultural events within a strong pan-European dimension. Valetta from Malta and Leeuwarden-Fryslân from Netherlands selected as The European Cultural Capital of 2018. To be a European Capital of Culture is an opportunity for the city to generate considerable cultural, social and economic benefits (Europa. eu, 2018). EU, UNESCO, and other partners act together to organize conventions and advertisement activities, short and long term projects to increase the interest of the designated city. In order to ensure the development of the designated city through cultural heritage tourism at a level and in a manner that the respective environments are capable of sustaining, would allow for tourism without sacrificing the attractions upon which it subsists. They also act together to anable future generations have the opportunities to benefit from their heritage (Drost, 1996: 483).

Tourism represents an indispensable source of financial resources for the preservation and restoration of the heritage when organized in a conscious way. Otherwise, the destination faces deficite in the budget and loose state transfers. In addition to advertising efforts, existing resources have to be promoted in conjunction with other forms of tourist attractions, spanning from events, to gastronomy, high-quality infrastructure and whole regional networks without losing from sight the necessity to bring about a diverse, original and attractive image. Ouerfelli (2008) indicated the factors that influence in attracting tourists to a destination. According to the author price and income, as well as rich cultural heritages are important tourist attractions. Garrod and Fyall (2000) emphasized that comfort, communication with the public, the accessibility of the destination and the atmosphere of the place are at the heart of the main factors that attract tourists to a destination. These attractions are only loosely connected with heritage preservation.

Russo \& Van Der Borg (2002) utilized the information gathered in four European cities and concluded that specific soft elements of the urban tourism product are the ones that matter most in determining the attractiveness of a destination for international visitors, and yet they are often overlooked by city planners. The authors suggested that if the conditions for "sustainable consumption" of cultural assets are not guaranteed, the enormous investments that in recent decades cities and regions are seeking for their cultural capital may be wasted. To have tourist potential, whatever the size, based on monuments, sights and attractions, is not sufficient for cities to establish themselves as tourist 
destinations. European cities have to plan for their tourism development paying due attention to those "intangible" elements like culture that decisively contribute to urban attractiveness. Russo (2002) also stated that there is a certain difficulty for cultural cities to maintain their attraction capacity. Destinations must create a tourist infrastructure of international standards and with a high degree of predictability that allows the destination to be attractive, not so much to the individual tourist, but rather to the tourist industry, and in particular to the trans-national players that dominate it. In the light of the extensive literature search and the studies mentioned above, there seem to be a necessity to conduct more studies of tourists attractions via cultural heritage in order to have greater knowledge of this issue.

\section{THE YEAR OF TROY}

Trojan Ruins was a city and a cultural center in the far northwest of Anatolia nearly 2000 years. Throughout history, there were at least nine cities built, one on top of the other. This feature is an indication that Troy is the cradle of many civilizations. The geography of Troy holds areas between two continents that's why it became the city of trade, wealth and wars. Troy is mentioned in the Iliad and Odyssey of Homer. According to these literal Works Paris, the Trojan prince, abducted Helen, wife of the Greek Menelaus, triggered a 10-year siege of Troy. When the troops could not capture Trojan Castle around 1200 BC, Ulysses, the Greek commander fooled the Trojans into thinking a huge wooden horse was a peace offering. The jubilant Trojans took the horse inner part of a fortress with victorious festivals. But they failed to realise Greek soldiers were hiding inside. This incident is seen as the first warfare deception in the history (Governorship of Canakkale, 2015). Thanks to all these characteristics, the ancient city of Troy, one of the most famous ancient cities in the world, was included in the UNESCO World Heritage List in 1998 (Culture and Tourism Ministry of Turkey, 2018) and the year 2018 is the twentieth anniversary of the inclusion of Troy into the UNESCO World Cultural Heritage. Due to the international recognition of the Troy, Turkey Culture and Tourism Ministry has declared the year 2018 as 'The Year of Troy' officially.

According to tourism statistics (2017) of Canakkale Province, which commands on the Trojan region, the number of tourists visiting Canakkale has increased regularly since 2003 (except for the years 2004, 2005 and 2016). According to the statistics, 1.159.795 tourists visited Canakkale in 2017 while this number was 287.934 in 2003. It is possible to say that these numbers are quite low for a destination like Canakkale, which has many natural and cultural attractions and has many alternative tourism potentials. When the tourism activities, between the years 2003-2017, are examined according to the duration of their overnight stays, the city faces a bad situation. 1.159.795 tourists only stayed in Canakkale for an average of 1,7 nights. while this number 1.83 in 2003. This average number has never been 2 nights between these years. Given the visits to the Troy region, it is seen that despite 1.159.795 tourists visited Canakkale in 2017, only 330.359 tourists chose to visit the Trojan area. In this context, The Year of Troy is thought to be important to introduce Turkey and Canakkale which has a rich 
historical background to the world as a better way. During 'The Year of Troy', the cultural, natural and historical values of the whole region will continue to be introduced besides the Trojan Ancient City. The Governor of Canakkale and the 2018 Troy Coordination Center authorities are carrying out works for the announcement of the 'The Year of Troy' to all the countries of the world. These authorities also participate in world-famous tourism fairs and introduce all the destinations of Canakkale, especially Trojan Ancient City. During this year new trip routes are being opened by the Canakkale Governorship coordination. Table one indicates the activities which are carried out during the first half of the year and planned to be implemented on local, national and international in the context of 'The Year of Troy'.

\section{Table 1. National and International Completed and Planned Activities}

\begin{tabular}{|c|c|}
\hline National Activities & International Activities \\
\hline $\begin{array}{l}\text { 'The Year of Troy' was introduced under the } \\
\text { coordination of CATOD and Canakkale } \\
\text { Governorship at the 11th Travel Turkey İzmir } \\
\text { Tourism Fair in January } 2018 \text {. }\end{array}$ & $\begin{array}{l}\text { Promotions were held at Canakkale-Troy stand in } \\
\text { Madrid, where tourists, agencies, national and } \\
\text { international sector representatives came together with } \\
\text { the 38th International Tourism Fair in Spain (IFEMA- } \\
\text { FITUR) fair in January } 2018 \text {. }\end{array}$ \\
\hline $\begin{array}{l}\text { Canakkale Provincial Culture and Tourism } \\
\text { Directorate exhibited the first painting and design } \\
\text { exhibition of 'The Year of Troy' in the name of "Troy } \\
\text { Dreams" in January } 2018 \text {. }\end{array}$ & $\begin{array}{l}\text { 'The Year of Troy' was introduced in South Asia } \\
\text { Travel and Tourism Fair (SATTE 2018) in New Delhi } \\
\text { in February } 2018 .\end{array}$ \\
\hline $\begin{array}{l}\text { 'The Year of Troy' was introduced at the East } \\
\text { Mediterranean International Tourism and Travel } \\
\text { Exhibition (EMITT) Fair which held at the TUYAP } \\
\text { Fair and Congress Center in Istanbul in January } 2018 .\end{array}$ & $\begin{array}{l}\text { In March 2018, 'The Year of Troy' was introduced at } \\
\text { ITB Berlin which is the world's largest tourism fair. }\end{array}$ \\
\hline $\begin{array}{l}\text { "Trojan Musical" was exhibited by the Anatolian Fire } \\
\text { Dance Community in January } 2018 \text { because of the } \\
\text { 20th anniversary of Troy's included in the UNESCO } \\
\text { World Cultural Heritage list. Before the Trojan } \\
\text { Musical, visuals and presentation were made in } \\
\text { Istanbul Ulker Sports and Activity Hall about } \\
\text { Canakkale and The Year of Troy. }\end{array}$ & $\begin{array}{l}\text { In March 2018, 'The Year of Troy' was introduced at } \\
\text { the 24th Ukraine International Tourism and Travel } \\
\text { Fair. }\end{array}$ \\
\hline $\begin{array}{l}\text { Castle Bicycle Festival was } \\
\text { scope of The Year of Troy in } M\end{array}$ & $\begin{array}{l}\text { eries of historic shoots } \\
\text { ce all over the world } \\
\text { City'. }\end{array}$ \\
\hline $\begin{array}{l}\text { Ministry of } \mathrm{Cu} \\
\text { entitled 'The } \mathrm{Yer} \\
\text { young designers }\end{array}$ & $\begin{array}{l}\text { In Mart 2018, International Canakkale Cycling } \\
\text { Festival was organized. }\end{array}$ \\
\hline & $\begin{array}{l}\text { onal Trojan Children's Folk } \\
\text { iized. }\end{array}$ \\
\hline $\begin{array}{l}\text { Within the scope of The Year of Troy, } 1 \text { st Troy } 2018 \\
\text { Robot and Project Competitions were organized by } \\
\text { Canakkale Provincial Directorate of National } \\
\text { Education in April. }\end{array}$ & $\begin{array}{l}\text { In April 2018, the Ministry of Culture and Tourism } \\
\text { held a conference on "Turks and Troy" in Chicago, } \\
\text { USA as part of The Year of Troy. }\end{array}$ \\
\hline $\begin{array}{l}\text { Canakkale Onsekiz Mart University Fine Arts } \\
\text { Faculty Teaching Staff organized a painting } \\
\text { exhibition in the scope of The Year of Troy activities } \\
\text { in May 2018. }\end{array}$ & $\begin{array}{l}\text { In April 2018, International Homeros Literature } \\
\text { Festival Writers' Meeting was organized. }\end{array}$ \\
\hline $\begin{array}{l}\text { In May } 2018 \text {, twelve beaches of Canakkale within the } \\
\text { scope of The Year of Troy were given the blue flag, } \\
\text { also called the international environmental award. }\end{array}$ & $\begin{array}{l}\text { In April 2018, Professor Aslan who is from } \\
\text { Archeology Department of Canakkale Onsekiz Mart } \\
\text { University and the President of the Troy Excavation } \\
\text { Area gave a conference in the cities of Canada's St. } \\
\text { John's, Ottawa and Toronto within the scope of the The } \\
\text { Year of Troy. }\end{array}$ \\
\hline
\end{tabular}




\begin{tabular}{|c|c|}
\hline $\begin{array}{l}\text { In May 2018, "The Year of Troy Student Festivals" } \\
\text { were held in Terzioglu and Dardanos Campuses } \\
\text { within the scope of The Year of Troy, which } \\
\text { Canakkale Onsekiz Mart University supported with } \\
\text { its all units. }\end{array}$ & $\begin{array}{l}\text { Canakkale and 'The Year of Troy' were introduced at } \\
\text { the ATB Dubai fair which is the largest tourism } \\
\text { meeting in the Middle East in April } 2018 \text {. }\end{array}$ \\
\hline $\begin{array}{l}\text { In May 2018, the 7th International Business } \\
\text { Management Congress was held at the Troia Cultural } \\
\text { Center in cooperation with the Business } \\
\text { Administration Department of the Faculty of Political } \\
\text { Sciences of Canakkale Onsekiz Mart University and } \\
\text { the Business Administration Department of the } \\
\text { Silesian University of Czech Republic. }\end{array}$ & $\begin{array}{l}\text { In May 2018, International Symposium on Troika } \\
\text { Excavation and Research Archaeometry was } \\
\text { organized. }\end{array}$ \\
\hline $\begin{array}{l}\text { In May 2018, students from Canakkale Science High } \\
\text { School Culture and Literature Club students } \\
\text { organized a poetry contest entitled 'Troy Poets' due to } \\
\text { The Year of Troy. }\end{array}$ & $\begin{array}{l}\text { In June 2018, Carraro Gallipoli Triathlon was held } \\
\text { within the scope of The Year of Troy. }\end{array}$ \\
\hline $\begin{array}{l}\text { In June 2018, Carraro Gallipoli Triathlon was held } \\
\text { within the scope of The Year of Troy. }\end{array}$ & In June 2018, the Trojan Exhibition opened in Zagreb. \\
\hline $\begin{array}{l}\text { The Troya Museum is the biggest investment within } \\
\text { the scope of The Year of Troy, which is planned to } \\
\text { open in August 2018, in Tevfikiye village of } \\
\text { Canakkale. }\end{array}$ & $\begin{array}{l}\text { Within the scope of The Year of Troy, World Famous } \\
\text { Friendship and Peace Rally's legs are planned to be } \\
\text { held in France, Germany, Austria, Slovenia, Hungary, } \\
\text { Romania, Bulgaria, Turkey, Israel, Palestine and } \\
\text { Jordan. In this context, in May 2018, the Turkey leg of } \\
\text { the rally has started from Canakkale with the name } \\
\text { "Troy 2018". }\end{array}$ \\
\hline
\end{tabular}

Compiled from: troya2018.com

Within the scope of 'The Year of Troy', 700 thousand tourists are expected to visit to the Trojan Ancient City (Tungut, 2017). The Troy region, which continues to attract attention in national and international platforms, is thought to attract visitors even more with the opening of the Troya Museum (Governorship of Canakkale, 2018).

\section{METHODOLOGY}

Study was designed as a qualitative research and semi-structured interview form was used for the data collection. There is immense value in gaining qualitative information from key individuals within communities and from assessing the role of different stakeholders in a given initiative. In this direction, the field related to Troy district was scanned and several field trips were made to determine the current situation. In addition, the literature review, which was then augmented by tourist brochures, websites, and advertisements, established the foundation for research questions and methodology (Everett \& Aitchison, 2008: 154). Therefore, in the research, more than one method is used together to make "data diversification" (Kerlinger and Lee, 2000).

The semi structured questions designed to identify and assess the opinions, priorities, goals and needs of key people that may significantly influence the potential effects of 'The Year of Troy' and they may have an impact on the community of Canakkale province. Purposeful sampling method was chosen as sampling method in this study. Creswell and Clark (2017: 112) define purposeful sampling as when researchers intentionally select participants who have experience with the central phenomenon or the 
key concept being explored. With this viewpoint, as a sample of the study the key stakeholders could include academicians, entrepreneurs, government officials and tourism executives, employees and tourists which are directly or indirectly influencing or influenced by the tourism industry (Simpson, 2007). Participants of the study were selected by taking into account the local stakeholders in Canakkale and the related units of central government. Table one indicates background of the interviewees and their respective occupations. The real names of the participants were kept confidential. In the scope of this study, the names of the participants were coded with ID letters in order not to specify the identities of the participants.

Semi-structured approximately 45 minute interviews were employed, incorporating a degree of flexibility within a predesigned interview structure. Received responses were recorded on the voice recorder and deciphered afterwards. After each question, the answer of the participants is summarized, so that it is aimed to prevent a mistake or error which may arise from the interpretation of the researcher during the analysis. 'Original' form of the data has been adhered when analyzing the results of in-depth interviews.

Descriptive analysis techniques were used in data analysis. In the descriptive analysis, the obtained data can be summarized and interpreted according to the previously determined themes. The data may also be presented by considering the questions or dimensions used in the interview process. In this type of analysis, a direct citation is given to reflect the opinions of all individuals (Y1ldirım \& Simsek, 2011). Data saturation is the collection of data up to the time when no new information is obtained (Morse, 1995). In the study, it was seen that the data was repeated after a point. Thus, it was decided that the data collection reached the saturation point and the interviews was completed with 17 people. The participants consisted of local and central stakeholders, national and international tourists. The international tourists were from western developed counties such as the U.K. and the Australia with a great deal of international travel experiences.

\section{RESEARCH QUESTIONS}

In the context of the study, the research questions are indicated below and these questions asked to the local and central stakeholders, domestic and foreign tourists:

- Would you assess the current situation of Canakkale province in terms of sustainable tourism?

- What should be done to attract tourists to Canakkale province?

- Are there any factors that negatively affect the development of tourism in the region? If so, what are these?

- Could you give information about the general operations and current status of tourism activities under the scope of The Year of Troy? 
- Is there organized work among the stakeholders in Canakkale within the scope of The Year of Troy?

- What are the effects of The Year of Troy activities on the regions economy?

- What are the social effects of The Year of Troy activities on the regions community?

- What are the environmental effects of The Year of Troy activities on Canakkale?

- Considering the natural structure of the region, how many tourists would be attaracted by the activities?

- Does a study have been done in the direction of how many tourists could be accommodated?

\section{RESEARCH FINDINGS}

The participants were grouped as; Local stakeholders and central stakeholders, national and international tourists. Seven participants have been living in Canakkalede for years and others (10 people) stay in Canakkale on average two days. Eight of the participants are women and nine are male. The participants, aged between 21-50 years and the average age is about 36 . In terms of the occupational areas, $41 \%$ of them work in public institutions.

Table 2. Demographic and Descriptive Information of Participants

\begin{tabular}{|c|c|c|c|c|c|}
\hline \multicolumn{6}{|c|}{ Characteristics of Local Stakeholders } \\
\hline ID & Age & Gender & Occupation Area & Occupation & $\begin{array}{l}\text { Duration of Being in } \\
\text { Canakkale }\end{array}$ \\
\hline $\mathrm{AD}$ & 44 & Male & Governorship of Canakkale & Unit Manager & 17 years \\
\hline YE & 38 & Male & Canakkale Municipality & Vice-Chairman & 38 years \\
\hline KB & 39 & Male & $\begin{array}{l}\text { Culture and Tourism } \\
\text { Directorate }\end{array}$ & Unit Manager & 21 years \\
\hline MS & 45 & Female & University & $\begin{array}{l}\text { Academician } \\
\text { (Tourism) }\end{array}$ & 20 years \\
\hline $\mathrm{ME}$ & 47 & Male & $\begin{array}{l}\text { Non-Governmental } \\
\text { Organization }\end{array}$ & Hotel manager & 21 years \\
\hline $\mathrm{HC}$ & 28 & Female & $\begin{array}{l}\text { Non-Governmental } \\
\text { Organization }\end{array}$ & Tourism Employee & 8 years \\
\hline $\mathrm{CN}$ & 41 & Male & $\begin{array}{l}\text { Non-Governmental } \\
\text { Organization }\end{array}$ & Tourist Guide & 20 years \\
\hline \multicolumn{6}{|c|}{ Characteristics of Central Stakeholders } \\
\hline FT & 49 & Male & $\begin{array}{l}\text { Ministry of Culture and } \\
\text { Tourism }\end{array}$ & $\begin{array}{l}\text { Deputy } \\
\text { Undersecretary }\end{array}$ & 3 days \\
\hline YS & 35 & Female & $\begin{array}{l}\text { General Directorate of } \\
\text { Cultural Assets and Museums }\end{array}$ & Branch Manager & 2 days \\
\hline \multicolumn{6}{|c|}{ Characteristics of Natinal Tourists } \\
\hline $\mathrm{OM}$ & 30 & Male & Service industry & Manager & 3 days \\
\hline LG & 37 & Female & High School & Teacher & 2 days \\
\hline $\mathrm{BO}$ & 38 & Male & Private Company & Supervisor & 2 days \\
\hline $\mathrm{ZU}$ & 40 & Female & Accounting & Controller & 2 days \\
\hline \multicolumn{6}{|c|}{ Characteristics of Internatinal Tourists } \\
\hline SR & 50 & Male & Agriculture & Sole Trader & 1 days \\
\hline
\end{tabular}


Yönetim ve Ekonomi Arasttrmaları Dergisi / Journal of Management and Economics Research

Cilt/Volume: $16 \quad$ Sayl/Issue: Özel Sayl/Special Issue Eylül/September 2018 ss./pp. 85-101

B. Eşitti, B. Buluk Doi: http://dx.doi.org/10.11611/yead.442147

\begin{tabular}{|c|c|c|l|c|c|}
\hline UT & 49 & Female & College & Teacher & 2 days \\
\hline MF & 21 & Female & Student & University Student & 3 days \\
\hline EJ & 29 & Female & Hospitality sector & $\begin{array}{c}\text { Departmant } \\
\text { Manager }\end{array}$ & 2 days \\
\hline
\end{tabular}

In this study, the themes are presented considering the open ended-questions used in the interviews. During the descriptive analysis process, firstly audio recordings analyses were resolved. The audio files are coded by reading them over and over again. After the coding process, the codes obtained were combined to determine their common features, and thus the themes that would form the outline of the research findings were found. Another expert has read and coded the interview forms that have been written. The coding was compared and found to be highly compatible with the coding obtained from the interview text. The code list and the themes that were created by referring to the expert opinion were given the final format. In this respect, it can be said that the research meets the reliability criteria. As Table two shows, 37 codes have been identified under the headings tourist attractions, sustainability, potential effects of The Year of Troy, expectations from The Year of Troy. The data organized according to themes, interpreted and explained and some direct citations are given under each theme.

Table 3. Distribution of Themes and Codes According to Interviewees ( $N=17)$

\begin{tabular}{|c|c|c|c|}
\hline Themes & Codes & Coding level & Frequency \\
\hline \multirow{13}{*}{ 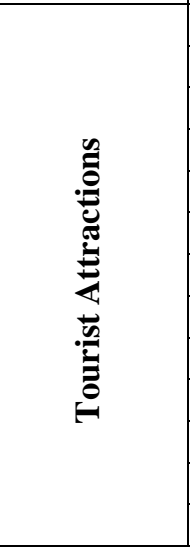 } & Marketing & 15 & 8,4 \\
\hline & Promotion & 16 & 8,9 \\
\hline & Product / Service diversification & 13 & 7,3 \\
\hline & Service Quality & 15 & 8,4 \\
\hline & Advertisement & 16 & 8,9 \\
\hline & Internet / Social media & 16 & 8,9 \\
\hline & Price policy & 14 & 7,8 \\
\hline & Fairs/Exhibitions/Conventions & 9 & 5,0 \\
\hline & Creating city image & 15 & 8,4 \\
\hline & Agreements with recognised tour operators & 8 & 4,5 \\
\hline & Safe/Satisfactory conditions around in tourism areas & 13 & 7,3 \\
\hline & Parking space & 14 & 7,8 \\
\hline & Entertainment \& Recreation & 15 & 8,4 \\
\hline \multirow{9}{*}{ 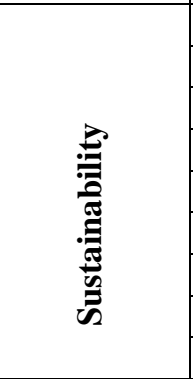 } & Clean/Well presented visitor facilities & 9 & 7,8 \\
\hline & Creating a responsible management body & 10 & 8,6 \\
\hline & Education & 13 & 11,2 \\
\hline & Limitation of waste/Unnecessary consumption & 16 & 13,8 \\
\hline & Environmental carrying capacity & 14 & 12,1 \\
\hline & Supporting local initiatives & 16 & 13,8 \\
\hline & Including thepublic Sector & 15 & 12,9 \\
\hline & Preservation of natural, social and cultural diversity & 15 & 12,9 \\
\hline & Not Exceeding the demands of the local community & 8 & 6,9 \\
\hline \multirow{7}{*}{ 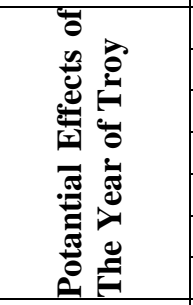 } & Coordination between institutions and sectors & 10 & 11,1 \\
\hline & Increase in number of tourists & 17 & 18,9 \\
\hline & Increase in tourists' spendings & 17 & 18,9 \\
\hline & Increase in the number of overnight stay & 14 & 15,5 \\
\hline & Public's Ad/Promotion boost & 15 & 16,7 \\
\hline & Public's financial support & 9 & 10 \\
\hline & Becoming an example of historical cultural sites & 8 & 8,9 \\
\hline \multirow{2}{*}{ 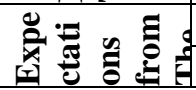 } & Increase in tourism sensitivity & 12 & 10,9 \\
\hline & Contribution to regional development & 16 & 14,6 \\
\hline
\end{tabular}


Yönetim ve Ekonomi Arastırmalart Dergisi / Journal of Management and Economics Research

Cilt/Volume: $16 \quad$ Sayl/Issue: Özel Sayl/Special Issue Eylül/September 2018 ss./pp. 85-101 B. Eşitti, B. Buluk Doi: http://dx.doi.org/10.11611/yead.442147

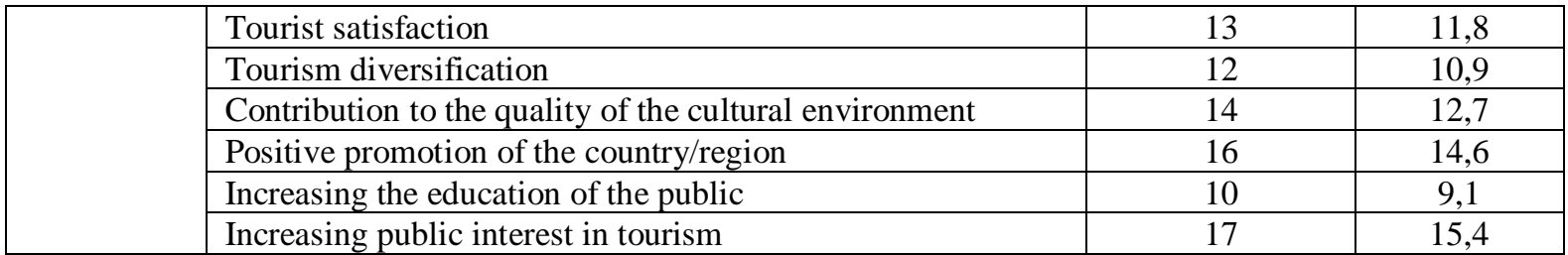

Table three shows the coding schemes grouped in the framework of the themes and the frequencies which these codings are referred to in the responses of interviewed persons. Attracting tourists is the most important achievement of 'The Year of Troy' in the views of the participants.

\subsection{TOURIST ATTRACTIONS}

According to the general view of the participants, many attempts have been made to attract tourists for 'The Year of Troy'. Among the initiatives taken to attract tourists, the participants are mostly mentioned the advertising, promotional activities and social media useages. In this regard, participant $\mathrm{AD}$ expressed as 'we can present advertisement and promotional work as one of the most important steps in planning and implementing 'The Year of Troy' events. In 2017, our local stakeholders had made a number of initiatives so that 2018 can be The Year of Troy. Advertising and promotion took place in social media, on the internet, in fairs and conventions and in many other places, especially before and after approval of the Culture and Tourism Ministry. We are still continuing these activities effectively and we can observe the return. At this point, the address of 'troy2018.com' has become an important information, advertising and promotion platform in itself.'

Participant MS expresses her opinion as follows 'One of the most important gains of this year's declaration as 'The Year of Troy' is undoubtedly attracting tourist and revival of tourism. Such conscious initiatives of the city's stakeholders bring to the city the image of culture and tourism. The obvious increase in the number of tourists also reveals the points that need to be developed in our city. For example, the lack of parking spaces in the city, the lack of entertainment and recreational activities can be counted as a significant number of points that negatively affect tourist satisfaction. This year we share these deficiencies with our local stakeholders.' As another opinion, YE has the following expression 'The Year of Troy' is creating a truly visible density in the city. Our plans for the second half of the year continue in the local sense. At the beginning of the pleasure that tourists bring to us is that the city is safe, they can walkaround with ease and that our cultural/historical places are in satisfactory conditions. This is good, but we observe especially the complaints of the local tourists about the high prices. I consider that prices are the reason for the low level of overnight stay in Canakkale.'

\subsection{SUSTAINABILITY}

Although the increase in tourist numbers and expenditures seemed to please local stakeholders, it was seen that the participants paid particular attention to the sustainable growth of tourism in the city. As a professional guide in the Troy region, $\mathrm{CN}$ commented on Canakkale's sustainable tourism and 
negative conditions affecting its development as follows 'Clearly the city has a limited carrying capacity. Especially local stakeholders struggle to increase the number of tourists. One of these efforts resulted in The Year of Troy. For example, last year, the first four months of 2017, 76,000 people visited the Troy ruins whereas the first four months of this year almost doubled to 143,000. This result shows that The Year of Troy meets expectations of local stakeholders. Especially the number of tourists increased this year, I am observing that the quality of service is decreasing. The interest shown when the number of tourists is low is not being shown as the number of tourist's increases. This is true from accommodation and transfer services to guidance services. This situation will adversely affect the development of tourism. While the increase in the number of tourists is welcomed positively, traffic, environmental pollution, inadequacy of accommodation services, lack of education of tourism workers and wastage are ignored. This indicates the lack of comprehensive planning. Instead of the rapid increase in the number of tourists, the infrastructure should be first established and improved. The central tourist areas such as Assos, Troy and Gallipoli are disconnected from each others. The limits of the city must be determined first, and after this achieved, a new offering should be created.'

Participant from national tourists LG has contributed as follows 'In general, our society is hospitable, but as tourism increases, various areas of interest and beneficiaries are emerging. At the beginning of these groups are mobile sellers. These people are trying to sell poor quality products by insisting on tourists. As far as I can see, this group gives the biggest damage to local tourism whereas there are professional places selling souvenirs related to the ruins. I do not understand why there are no precautions for these sellers.'

YE, as a manager at a five-star accommodation business in the area, expresses his opinion as ' $I$ think that our region can meet the increase of tourists in terms of accommodation capacity. In general, the accommodation enterprises in our region are certificated by the municipalities. According to the 2016 data 19.000 bed capacity belongs to the municipality certified enterprises whereas 6.099 belongs to the tourism operation certified enterprises. Our historical sites like the Trojan region are not actually in the city, but the accommodation businesses are in the city. This can cause difficulties in inspection, distribution, sales and marketing. We see that the new five-star hotels are still being built in the city center. However, only investment in areas outside the city and close to our historical sites such as Troy and Assos must be allowed. Similar investments that exceed the city center's carrying capacity should no longer be allowed. Then, the negative effects of increase in number of tourists in the region decreases. I should also mention the trojan museum at this point. It will be open in 'The Year of Troy' this year. It is a large complex established outside the city and in harmony with the structural character of the region.'

FT, who works in Ministry of Culture and Tourism, comments as follows 'The Year of Troy is contributing economically to Canakkale province, in addition to this, The Year of Troy reminded us how valuable our historical/cultural assets. There are traces of nine different civilizations in the ruins of 
Troia. These assets show how valuable the Troy is. Canakkale has three cultural values in the World Heritage lists which created by UNESCO (United Nations Educational, Scientific and Cultural Office). Only Troy ruins is on the World Heritage permanent List. Gallipoli World War I areas and Assos are included in the World Heritage Tentative List. We are improving sustainable access to these areas and we have implemented a number of projects to date to protect, clean and restore these areas. We support any necessary projects that have been carried out. For instance, handicrafts and souvenir courses were given to the villagers of Teşvikiye in cooperation with a private company and the Directorate of Public Education Center. In terms of sustainability, these courses were very helpful in ensuring that the people of the region are professionally earning income from tourism. These courses have taught them how to be hospitable, what to do for the satisfaction of the tursits and how to appreciate our local values in tourism.'

\subsection{POTENTIAL EFFECTS OF 'THE YEAR OF TROY'}

Participants in general noted that 'The Year of Troy' promoted regional tourism, increased number of tourists, revenues and coordination among tourism stakeholders in the first half of the year. So the 'The Year of Troy' can be said to be perceived positively by the interviewees. YS who works in the General Directorate of Cultural Assets and Museums has said as follow 'In The Year of the Troy's implementation, the associations such as ÇATOD (Canakkale Touristic Hotel Association) took the initiative in the first place and the central government declared this year as 'The Year of Troy ' and supported it financially with advertisements and promotions. Provincial Special Administration, Governorate, other public institutions, public organizations and non-governmental organizations, we work together at the ongoing sub-structure studies in the ancient city of Troy. Renovation and rehabilitation work of Tevfikiye Village continues as well. I am witnessing such a coordination and cooperation between the public and private sectors for the first time in this region. This coordination naturally contributes positively to the tourism of the region. In general, central government's interest in Canakkale undoubtedly facilitates the work of local stakeholders. I think the dedicated works and positive outcomes achieved through the 'The Year of Troy' will be a good example to many destinations in Turkey.'

MS who works as an academician in the University in Canakkale expresses the effects of 'The Year of the Troy' as 'Homer's Iliad is one of the most important works of the world ancient-literature. It tells the Trojan battles. So, ancient city of Troy is probably Turkey's one of the best-known historic site all over the world. This area had been destroyed and rebuilt nine times over the course of history. So the traces of many civilizations are still alive. 'The Year of Troy' revived interest in this region. Many events in the first six months of the year have contributed to tourism locally. Local events will continue in the second half of the year. Events held at national level also bring sound. As far as I follow, Turkey is hosting a series of events including a UNESCO Conference, International Council of Museums 
meetings and a World Tourism Forum. The State Theaters and State Opera and Ballet also put on shows with the theme of Troy. These broad-minded activities contributed positively to the promotion of all Turkey's tourism as well as Canakkale'

\subsection{EXPECTATIONS FROM THE YEAR OF TROY}

Most of the participants in this study are expecting that 'The Year of Troy' to contribute to the economy of the region and positive promotion of the region and the country. They expect that the activities organized in this context to enhance the satisfaction of tourists who interested in history and culture. They also expect that tourist's high interest in 'The Year of Troy' activities will increase investment for culture and history like 'Trojan Museum' and that promotional activities will educate / raise awareness of local people. Especially local stakeholders are very hopeful about the positive impact of 'The Year of Troy'.

$\mathrm{HC}$, who is working in a hotel close to the ancient city of Troy, expressed her expectations about 'The Year of Troy' as follow 'This year I could say that our people were really bombarded with information about the Troy. My expectation is the continued sensitivity to protect the ruins. Tourism is a smokeless industry but it needs tourism assets. Tourism workers such as myself are living thanks to these assets. The national and international initiatives under 'The Year of Troy' increased our solidity ratio. Not just for us, you can see that there are a lot of small scale businesses for tourism in this region. I expect that these promotional activities will not be limited to this year and will continue. For example in the local sense, open-air theaters and concerts were organized in the city center. These activities gathered both our interest in Troy and trained our people. Many areas in our region have historical and cultural significance. I hope that through this awareness, our cultural / historical areas will be preserved and that quality investments will be made.'

\section{DISCUSSION AND CONCLUSION}

Stakeholders of a destination can fulfill important functions in order to provide sustainable tourism for the destination. This study reveals that local and national stakeholders work coordinaly in the anniversary of Troy's entry into the UNESCO World Heritage list and how this cooperation influences the local tourism. It is seen that local tourism stakeholders can create a consciousness in central government and local-central cooperations revitalize tourism in particular. Heritage/cultural tourism facilities are open to similar initiatives. The number of tourists interested in heritage and culture tourism is also increasing day by day. For example, through promotions and advertisements, 100 thousand tourists even go abroad and watch the royal marriage ceremony of a British prince, which had been designed to reflect British history and culture (Express, 2018). As in the case of Troy, anniversaries related to the history of humanity and culture that can create similar international interest in Turkey. 
Exhibitions, festivals and theatrical events related to the Trojan War and Ilyada epic can be increased with international advertisements and promotions.

Local stakeholders are very hopeful about the positive impact of 'The Year of Troy' on Canakkale's tourism and they are continuing to work in this direction. Financial, promotion and advertising supports provided by the central government to the local stakeholders and investment in harmony with the historical and cultural assets of the region, such as the Troy Museum, strengthen the grip of local stakeholders and enhance tourism attractiveness. It is necessary for national and local unity to be maintained and long-term growth plans to be carried out for the sustainability of this revival.

While positive steps are being taken in developing heritage tourism in Canakkale, it is seen that sensitive ecosystem has not been tried to be preserved in the same way. Most of the participants in this study complained about modern tourism investments made in the city center which adversely affect the carrying capacity of the city. Primarily, the average overnight stay in Canakkale is quite low. The problem is not the lack of adequate accommodation businesses. The tourism activities that can be done in the city are not related to one another. Therefore connection paths should be established between tourism values such as Troy, Assos, Gallipoli peninsula and islands. At this point, travel agencies and tourist guides should take responsibility with creating routes to increase the length of stay of visitors and promote Canakkale region. On the other hand, rehabilitation and renovation works of Tevfikiye Village in Troy region, which is prominent with its historical, mythological, cultural assets, are being carried out within the scope of 'The Year of Troy' and the sustainable development of the region is ensured.

The concept of sustainability needs to be adopted by all stakeholders. The visitors do not only see the ancient historical remains and the surrounding area, but also they spend time in the whole city. In addition to increasing the accommodation capacity, measures must be taken to the city traffic, wastage management, environmental pollution and employee training to ensure guest satisfaction. Tourism development by attracting tourists only in numerical sense brings with peculiar problems and costs that may hamper the long-term viability of the destination's development. It is therefore necessary that the tourism planners and stakeholders anticipate such tendencies, bringing together development and sustainability (Russo \& Van Der Borg, 2002).

As a result, 'The Year of Troy' activities seem to have contributed positively to attracting and introducing the city to tourists. Locally, introduced the assets in the city and it is understood that national-international promotion initiatives will continue with many planned activities for the second half of the year. But it is necessary to evaluate the region as a whole and to set the sustainable targets in addition to the purpose of increasing the tourist numbers. The present study includes several limitations. First, as indicated earlier the research is based only on the first six months of the year. The data collection was done only in Canakkale province and demographics and motivations of the participants are not 
considered in this study which can be important factors. The future researches can be further deepened and broadened by taking whole year and mentioned factors into account.

\section{REFERENCES}

Anonymous. (2002) “Türkiye’nin Turizm Değerleri”, (Vol. II), Ankara: T.C. Turizm Bakanlığı Yatırımlar Genel Müdürlügü Yayınları.

Cimen, M. (2018) “Türkiye Çağ Atladı”, https://www.aksam.com.tr/guncel/turkiye-cag-atladi/haber$\underline{731331},(02.05 .2018)$.

Creswell, J.W. and Clark, V.L.P. (2017) “Designing and Conducting Mixed Methods Research”, Sage Publications.

Culture and Tourism Ministry of Turkey (2018), “Truva Antik Kenti”, http://basin.kulturturizm.gov.tr/TR,45525/truva-antik-kenti.html, (04.05.2018).

Deng, J., King, B. and Bauer, T. (2002) "Evaluating Natural Attractions for Tourism", Annals of Tourism Research, 29(2): 422-438.

Drost, A. (1996) "Developing Sustainable Tourism for World Heritage Sites", Annals of Tourism Research, 23(2): 479-484.

Europa.eu (2018) "European Year of Cultural Heritage", https://europa.eu/culturalheritage/news/frisians-and-festa-european-capitals-culture-2018_en, (05.05.2018).

Everett, S. and Aitchison, C. (2008) “The Role of Food Tourism in Sustaining Regional Identity: A Case Study of Cornwall, South West England" Journal of Sustainable Tourism, 16(2): 150-167.

Express (2018) "Major Tourism 'Boom' Next Month As Thousands Flock to See Meghan Markle in Wedding Dress", https://www.express.co.uk/news/royal/949791/royal-wedding-2018-tourismboom-thousands-meghan-markle-prince-harry, (08.05.2018).

Garrod, B. and Fyall, A. (2000) "Managing Heritage Tourism”, Annals of Tourism Research, 27(3): $682-708$.

Governership of Canakkale (2018) "Çanakkale 2018 Troya Y1lıyla Dünyaya Açılıyor”, http://www.canakkale.gov.tr/canakkale-2018-troya-yiliyla-dunyaya-aciliyor, (09.05.2018).

Gössling, S., Hansson, C. B., Hörstmeier, O. and Saggel, S. (2002) "Ecological Footprint Analysis as a Tool to Assess Tourism Sustainability”, Ecological Economics, 43(2-3): 199-211.

Kerlinger, F. N. and Lee, H. B. (2000) “Foundations of Behavioral Research”, USA: Wadsworth.

Korkut, A. (2017) “Çanakkale'nin Bir Değeri Daha UNESCO Dünya Mirası”, http://www.bigazete.com.tr/2017/5/canakkalenin-bir-degeri-daha-unesco-dunya-mirasih26413.html, (11.05.2018). 
Morse, J.M. (1995) “The Significance of Saturation”. Qualitative Health Research, 5(2): 147-149.

Russo, A. P. and Van Der Borg, J. (2002) “Planning Considerations for Cultural Tourism: A Case Study of Four European Cities", Tourism Management, 23(6): 631-637.

Ouerfelli, C. (2008) "Co-integration Analysis of Quarterly European Tourism Demand in Tunisia", Tourism Management, 29(1): 127-137.

South Marmara Development Agency (2016) "Çanakkale'de Turizm", http://www.investincanakkale.com/tr/26972/canakkalede-turizm, (12.05.2018).

Yıldırım, T. B., Ak, T. and Ölmez, Z. (2008) "Assessment of the Natural-Cultural Resources in Çanakkale for Nature-Based Tourism, Environment, Development and Sustainability", 10(6): $871-881$

Yıldırım, A. and Şimşek, H. (2011) “Sosyal Bilimlerde Nitel Araştırma Yöntemleri”, Ankara: Seçkin Yayınevi.

World Heritage List (2018) "Properties Inscribed on the World Heritage List", https://whc.unesco.org/en/statesparties/tr, (12.05.2018). 